1 Favaloro, R. G., et al., fournal of Thoracic and Cardiovascular Surgery, 1967, 54, 359.

2 Johnson, W. D., Flemma, R. J., and Lepley, D. Jnr., Annals of Thoracic

Surgery, 1970, 9, 436.
Grondin, C. M., et al., Circulation, 1971, 44, 815.

Grondin, C. M., et al., Circulation, 1971, 44, 815.

5 Arderman, E. L., et al., New England Journal of Medicine, 1973, 288, 535.

- Wright, J. S., et al., Medical fournal of Australia, 1974, 1, 57.

British Medical fournal, 1972, 2, 603.

Gott, V. L.) American fournal of Cardiology, 1974, 33, 431.

- Anderson, R. P., et al., Annals of Thoracic Surgery, 1972, 63, 353

10 Cooley, D. A., et al., Annals of Thoracic Surgery, 1974, 17, 211.

11 Balcon, R., et al., British Heart Fournal, 1974, 36, 841.

13 Oberman, A., et al., Bulletin of the New York Academy of Medicine, 1972,

48, 1109 .
14 Bruschke, A. V. G., Proudfit, W. L., and Sones, F. M., Circulation, 1973, $47,1147$.

15 Ross, R. S., et al., Medical fournal of Australia, suppl. No. 1, 2, 6.

Proudfit, W. L., Shirey, E. K., and Sones, F. M., Circulation, 1966, 33, 901

${ }^{7}$ Amsterdam, E. A., Wolfson, S., and Gorlin, R., American fournal of Cardiology, 1969, 23, 104.

18 Cohen, M. V., et al., Circulation Supplements, 1972, 45-46, No. 1, p. 57 19 Gotsman, M. S., Lewis, B. S., and Bakst, A., South African Medical fournal, 1973, 47, 641 .

20 Mobert, C. H., Webster, J. S., and Sones, F. M., American fournal of Cardiology, 1972, 29, 282.

${ }^{21}$ Lichtlen, P. R., and Moccetti, T., Circulation Supplements, 1972, 45-46, Nos. 2-7.

${ }_{22}^{2}$ Walker, J. A., et al., Circulation Supplements, 1972, 45-46, No. 1, p. 86. 23 Hallin, R. W., et al., American fournal of Surgery, 1971, 122, 164.

24 Bourassa, M. G., et al., Circulation Supplements, 1972, 45-46, No. 1, p. 79. 25 Bemis, C. E., et al., Circulation, 1973, 47, 455.

26 Rees, G., et al., New England fournal of Medicine, 1971, 284, 1116.

27 Chatterjee, K., et al., New England fournal of Medicine, 1972, 286, 1117.

${ }^{28}$ Friedberg, C. K., Circulation, 1972, 45, 727.

29 Bousvaros, G., Chandry, M. A., and Piracha, A. R., American fournal of Cardiology, 1972, 29, 255.

30 Downs, A. R., and Morrow, I. M., Surgery, 1972, 72, 699.

${ }_{31}$ Lewis, B. S., and Gotsman, M. S., Thorax, 1974, 29, 209.

${ }_{32}$ British Medical fournal, 1973, 3, 601.

\section{Night Terrors}

The night terror (pavor nocturnus or incubus) is perhaps the most fearful of human experiences yet it is transient and leaves little lasting memory. It afflicts most children at some time and occasionally adults too. Attacks occur mainly in the first hour or two of sleep. A few strangled words or cries precede bloodcurdling shrieks; the child sits up and stares wide-eyed. He may stumble out of bed or by movement, words, and expression reveal how he would seek to avoid some horror. Oblivious of his parents and of their soothing words he does not see their own alarmed faces. Within minutes he is again sleeping soundly and in the morning remembers nothing untoward.

Where night terrors have lately become much more frequent a relation to day-time anxiety can usually be seen-a recent stay in hospital by the child, 1 absence from home of the mother, a change of house, a new school, the death of a grandparent or school-friend, a fire in a neighbour's house, a marital crisis between the parents, or, in the case of adults, a recent motor accident or wartime battle experience. Yet it must be emphasised that night terrors occur also in those in whom there is no evidence of neurotic disorder by day. ${ }^{23}$ They will occur in epileptic as in non-epileptic children, as will enuresis or sleep-walking; but like these latter, and notwithstanding the explosive drama, night terrors are not epileptic phenomena. ${ }^{4}$

In recent years Fisher et al. $^{5-7}$ have applied electrophysiological techniques and intensive post-terror questioning to many adult patients. The night terror differs from the nightmare in that it comes early in the night and arises from nonrapid eye movement sleep with large, slow electrical brain waves instead of from the rapid eye movement (R.E.M.) stage of sleep most closely associated with vivid dreaming. It is abrupt and is not a gradual development of a dream adventure; the heart rate rises not gradually over a minute or more but abruptly from perhaps 60 to 160 /minute in the space of 15 seconds, together with violent respirations. The deeper the sleep (to judge by the slowness of the E.E.G. waves) and the longer this deep sleep episode has just lasted the more severe the terror. Sometimes the anguished cries for help, the agonized cursings, seem to lead out of simpler mental life that questioning reveals was present just before the attack. Commonly the words betray fear of attack by persons or animals, fear of entrapment, fear of falling, dying, or of choking. Generally it seems as if the night terror is part and parcel of a spontaneous, natural arousal from deep sleep, such as occurs many times every night. Alertness and anxiety are commonly in parallel and drugs that diminish one usually diminish the other. Even though their brain mechanisms must be separate, in the night terror anxiety-arousal and wakefulness-arousal may be being activated together when they should not. Diazepam has been found effective for adult sufferers ${ }^{6}$ and imipramine has been advocated for children ${ }^{8}{ }^{9}$ but at such an age is best avoided.

The parents of the child suffer much distress, and it is they who should be reassured that no grave psychological abnormality or damage is signified, that the child will have no memory of his attacks, and that time will bring amelioration. Environmental stress in housing or family interplay can sometimes be pin-pointed, when the night terrors will provide an incentive for new solutions.

1 Levy, D., American fournal of Diseases of Children, 1945, 69, 7

2 Gastaut, H., and Broughton, R., Recent Advances in Biological Psychiatry,

${ }^{3}$ Mack, J. E., Nightmares and Human Conflict. Boston, Little, Brown and Company, 1970.

4 Tassinari, C. A., et al., Electroencephalography and Clinical Neurophysiology, 1972, 33, 503.

5 Fisher, C., et al., fournal of the American Psychoanalytic Association, 1970, $18,747$.

7 Fisher, C., et al., Archives of General Psychiatry, 1973, 28, 252.

8 Pesikoff, ${ }^{\circ}$ et al., Fournal of Nervous and Mental Disease, $1974,158,174$. 128, 778 .

- Tec, L., Fournal of the American Medical Association, 1974, 228, 978.

\section{Chemoprophylaxis against Tuberculosis}

The term chemoprophylaxis against tuberculosis has many shades of meaning. It has been used to describe prophylaxis on a community-wide basis, ${ }^{12}$ so including both individuals already infected and those non-infected. More accurately, the term is given to the prevention of infection, sometimes called primary chemoprophylaxis. Disease or secondary prophylaxis describes the use of drugs to prevent disease in positive tuberculin reactors. Chemoprophylaxis has also been used to describe treatment intended to prevent relapse of apparently inactive, tuberculosis, either untreated or inadequately treated. Finally it is used to describe treatmentincreasingly advocated nowadays-in tuberculin positive reactors receiving prolonged therapy with high doses of steroids or with cytotoxic drugs.

Isoniazid is commonly used alone in antituberculosis chemoprophylaxis, because it is effective, cheap, acceptable, and has few side effects. Fears that isoniazid resistant organisms would emerge have proved unfounded, ${ }^{3}$ and with the discovery of several other effective antituberculosis drugs available in reserve there has been less reluctance to use isoniazid alone. The maximum daily dose of isoniazid is usually $300 \mathrm{mg}$ (or $10 \mathrm{mg} / \mathrm{kg}$ for children) given for one year. 